\title{
Isotherm, Kinetic and Thermodynamic Studies on the Adsorption of Cd (II) and Zn (II) ions from Aqueous Solutions onto Bottom Ash
}

\author{
Hatairat Sukpreabprom, Orn-Anong Arquero, Wimol Naksata, Ponlayuth Sooksamiti, and \\ Sorapong Janhom
}

\begin{abstract}
Bottom ash is a waste material obtained from electricity generation through combustion of coal at the Mae Moh power plant in Thailand. The adsorption of Cd (II) and Zn (II) ions from aqueous solutions onto bottom ash was studied using batch experiments. The effect of $\mathrm{pH}$, contact time and temperature were investigated. Adsorption isotherm data for metal ions was analyzed by the Langmuir and Freundlich isotherms. The Freundlich isotherm properly described the adsorption data for all studied temperatures. The results revealed that the adsorption kinetics followed pseudo-second-order kinetic model. Thermodynamic parameters such as Gibbs free energy change $\left(\Delta \mathbf{G}^{\circ}\right)$, enthalpy change $\left(\Delta \mathbf{H}^{\circ}\right)$ and entropy change $\left(\Delta \mathbf{S}^{\circ}\right)$ were investigated. The calculated values showed that the adsorption process for both Cd (II) and Zn (II) ions was endothermic.
\end{abstract}

Index Terms-Bottom ash, adsorption, isotherm, kinetic, thermodynamic.

\section{INTRODUCTION}

A serious environmental problem is toxic heavy metals contamination of wastewater. Heavy metal ions are released into water from many industries such as mining, chemical manufacturing, battery manufacturing, electroplating, coating and pigment [1], [2]. Cadmium (Cd (II)) and Zinc (Zn (II)) are common pollutants widely found in industrial wastewater. Cd (II) has been well recognized for its negative effect on the environment. It is a non-essential and non-biodegradable component which readily accumulates in living systems. A number of acute and chronic disorders, such as itai-itai disease, renal damage, emphysema, hypertension, and testicular atrophy are harmful effects of $\mathrm{Cd}$ (II) [3]. Zn (II) is an essential trace element for humans in enzymatic reactions. However, excessive intake of $\mathrm{Zn}$ (II) may cause toxic effects such as carcinogenesis, mutagenesis and teratogenesis as a result of its bioaccumulation [4]. Therefore, from an environmental point of view, a study on the removal of $\mathrm{Cd}$ (II) and $\mathrm{Zn}$ (II) ions is one of considerable significance.

Manuscript received August 15, 2013; revised September 27, 2013. This work was supported in part by the Graduate School of Chiang Mai University, Thailand.

Hatairat Sukpreabprom, Orn-Anong Arquero, Wimol Naksata, and Sorapong Janhom are with the Department of Chemistry, Faculty of Science, Chiang Mai University, Chiang Mai, Thailand (e-mail: hatairat278@gmail.com, orn.arquero@gmail.com, scchi021@chiangmai.ac.th, sorapongj@gmail.com).

Ponlayuth Sooksamiti is with the Department of Primary Industry and Mine Office Region 3, Chiang Mai, Thailand (e-mail: sooksamiti@hotmail.com).
The conventional methods for removal of heavy metal ions from industrial effluents include chemical precipitation, coagulation, solvent extraction, electrodialysis, reverse osmosis, ion exchange, evaporation and filtration. However, the application of these methods is restricted due to technical complexity and economical constraint. Adsorption process is one of the most common methods used in wastewater treatment because of its low cost, simplicity and high efficiency [5]-[7]. The important characteristics of adsorbent are the adsorption capacity, selectivity, possibility of regeneration, reaction velocity, compatibility and price. Adsorption capacity depends on surface area, pore size, diameter and chemical composition of the adsorbent. Activated carbon has been widely used in adsorption process because it has high specific surface area and pore volume. Activated carbon is regarded as an effective adsorbent but the removal of heavy metal ions by adsorption with activated carbon is relatively expensive. At present, attentions have been focused on the development of low cost adsorbent for wastewater treatment application. The materials considered to produce adsorbent are industrial and agricultural wastes such as clay, peat, rice husk, fly ash, sawdust, red mud, manganese nodule residue and oxide-coated sands etc. [8], [9].

The Mae Moh power plant is the largest lignite coal-burning power plant in Thailand. The generation of electricity through combustion produces a huge amount of waste such as fly ash, bottom ash and boiler slag. The wastes from coal-burning power plant can be the source of pollution. Therefore, the utilization of these wastes has been developed. From the coal-burning process, the amount of bottom ash is approximately $20 \%$ by weight of the total ash. It is made from agglomerated ash particles that are too large to be carried in the flue gases and fall through open grates to an ash hopper at the bottom of the furnace. Bottom ash, which is porous, coarse, glassy and granular material, has already been used as aggregate in concrete and road base material. Recently, several studies have reported the use of bottom ash as adsorbent for the removal of various heavy metals. The physical characteristics of bottom ash are small particle size, high porosity and large surface area. Due to these properties, it is a good choice for use as a potential adsorbent [10]-[12].

The objective of this research is to investigate the possibility of using bottom ash as an adsorbent for removal of $\mathrm{Cd}$ (II) and $\mathrm{Zn}$ (II) ions from aqueous solutions. The effect of $\mathrm{pH}$, contact time and temperature were studied by batch experiments. The equilibrium data would be analyzed using Langmuir and Freundlich isotherm models. Furthermore, the adsorption kinetics and thermodynamic parameters for adsorption process of heavy metal ions onto bottom ash were also evaluated. 


\section{MATERIALS AND MethodS}

\section{A. Preparation of Adsorbent}

Bottom ash used as adsorbent in this study was obtained from Mae Moh power plant in Thailand. It was dried at $110^{\circ} \mathrm{C}$ for 24 hours in order to reach constant weight. The dried bottom ash was crushed and sieved to 80 mesh $(0.177 \mathrm{~mm})$. The prepared material was stored in desiccators for further use.

\section{B. Chemicals}

All the chemicals used were analytical reagent (AR) grade. Cadmium nitrate tetrahydrate $\left(\mathrm{Cd}\left(\mathrm{NO}_{3}\right)_{2} \cdot 4 \mathrm{H}_{2} \mathrm{O}\right)$ was procured from Fluka, Switzerland. Zinc nitrate hexahydrate $\left(\mathrm{Zn}\left(\mathrm{NO}_{3}\right)_{2} \cdot 6 \mathrm{H}_{2} \mathrm{O}\right)$ was procured from Carlo Erba, Italy. Nitric acid $\left(\mathrm{HNO}_{3}\right)$ was purchased from RCI Labscan, Thailand. Sodium hydroxide $(\mathrm{NaOH})$ was purchased from Merck, Germany. Stock solutions of Cd (II) and Zn (II) (1000 mg/L) were prepared by dissolving exact amount of $\mathrm{Cd}\left(\mathrm{NO}_{3}\right)_{2} \cdot 4 \mathrm{H}_{2} \mathrm{O}$ and $\mathrm{Zn}\left(\mathrm{NO}_{3}\right)_{2} \cdot 6 \mathrm{H}_{2} \mathrm{O}$ in deionized water, respectively. Solutions of $1 \mathrm{M} \mathrm{HNO}_{3}$ and $1 \mathrm{M} \mathrm{NaOH}$ were used for $\mathrm{pH}$ adjustment.

\section{Characterization of Adsorbent}

The physical and chemical characteristics of bottom ash were performed by conventional methods. The $\mathrm{pH}$ of bottom ash was measured using pH meter (Model pHTestr20, Eutech instruments, Singapore). A specific gravity bottle was used to determine the density of the adsorbent. The moisture content was carried out according to ASTM D 2216-98. The cation exchange capacity (CEC) was measured to evaluate the adsorption capacity using Kjeldahl microsteam apparatus after saturation with ammonium acetate. The particle size of bottom ash was determined using particle size distribution analyzer (Model Mastersize 2000, Malvern instruments, UK). The specific surface area was determined by the Brunauer-Emmett-Teller (BET) method using Quantachrome Autosorb automate with nitrogen gas (version 2.46). The Phillips MagiX PRO PW 2400 Sequential X-ray fluorescence (XRF) Spectrometer using Rhodium (Rh) tube was used for chemical compositions determination of bottom ash.

\section{Batch Adsorption Studies}

For each experiment, the $100 \mathrm{~mL}$ of $50 \mathrm{mg} / \mathrm{L}$ metal solutions was added to erlenmeyer flask containing $0.1 \mathrm{~g}$ of bottom ash. All Batch experiments were carried out in water bath shaker (Model WSB-45, Daihan scientific, Korea) with a $150 \mathrm{rpm}$ shaking rate at $30^{\circ} \mathrm{C}$. The effect of solution $\mathrm{pH}$ was studied in the $\mathrm{pH}$ range of 4-6. The initial $\mathrm{pH}$ of solution was adjusted with $1 \mathrm{M} \mathrm{HNO}_{3}$ or $1 \mathrm{M} \mathrm{NaOH}$ solution. After 5 hours of contact time, the supernatant was separated by filtration and analyzed for the residual concentrations of $\mathrm{Cd}$ (II) and Zn (II) by atomic absorption spectrophotometer (AAS) (Model 3110, Perkin Elmer, USA). The amount of metal ion adsorbed, $q_{e}(\mathrm{mg} / \mathrm{g})$, was calculated using the following equation:

$$
q_{e}=\frac{\left(C_{0}-C_{e}\right) V}{m}
$$

where $C_{0}$ is the initial metal ion concentration $(\mathrm{mg} / \mathrm{L}), C_{e}$ is the equilibrium metal ion concentration $(\mathrm{mg} / \mathrm{L}), V$ is the volume of solution $(\mathrm{L})$ and $\mathrm{m}$ is the mass of the adsorbent $(\mathrm{g})$.

\section{E. Adsorption Kinetics}

The kinetic studies were also performed using batch experiments. In each flask contained $0.1 \mathrm{~g}$ of bottom ash and $100 \mathrm{~mL}$ of aqueous solutions was used. The experiments were carried out with initial concentration of $50 \mathrm{mg} / \mathrm{L}$ for all metal solutions at $30^{\circ} \mathrm{C}$ and $\mathrm{pH}$ 6. This $\mathrm{pH}$ was found to be the optimum on the basis of the effect of $\mathrm{pH}$ test. The adsorption of metal ions on bottom ash at various times (10, $20,30,60,90,120,180,240$ and 300 minutes) was measured to determine the effect of contact time.

Sorption kinetics can be used to describe the controlling mechanism of adsorption process. The two kinetic models, pseudo-first-order and pseudo-second-order, were used to investigate the fit experimental data from the adsorption of $\mathrm{Cd}$ (II) and $\mathrm{Zn}$ (II) ions onto bottom ash.

\section{1) Pseudo-first-order model}

The adsorption kinetic data is evaluated using the pseudo-first-order equation (Lagergren's equation), which can describe the adsorption rate based on the sorption capacity of solids. The linear form of pseudo-first-order model can be expressed as:

$$
\log \left(q_{e}-q_{t}\right)=\log q_{e}-\frac{k_{1}}{2.303} t
$$

where $q_{e}$ and $q_{t}$ are the amount of metal ion adsorbed at equilibrium and at time $t(\mathrm{~min})$, respectively $(\mathrm{mg} / \mathrm{g})$ and $k_{1}$ is the rate constant of pseudo-first-order adsorption $\left(\mathrm{min}^{-1}\right)$.

2) Pseudo-second-order model

The adsorption kinetic may also be described by the pseudo-second-order model. The equation for linear form is:

$$
\frac{t}{q_{t}}=\frac{1}{k_{2} q_{e}^{2}}+\frac{1}{q_{e}} t
$$

where $k_{2}$ is the rate constant of pseudo-second-order adsorption (g/mg.min) and $k_{2} q_{e}^{2}$ or $h$ is the initial adsorption rate (mg/g.min) [13], [14].

\section{F. Adsorption Isotherms}

Adsorption isotherms were obtained by varying the initial concentration of metal ions from 5 to $50 \mathrm{mg} / \mathrm{L}(5,10,15,20$, $25,30,40$ and $50 \mathrm{mg} / \mathrm{L})$ at different temperatures $(10,20,30$ and $40^{\circ} \mathrm{C}$ ). The adsorption conditions were controlled the same as in adsorption kinetic studies and 60 min was selected as contact time. In previous kinetic experiments, 60 min was proved to be sufficient for adsorption of Cd (II) and $\mathrm{Zn}$ (II) ions onto bottom ash to reach equilibrium.

Adsorption isotherm can explain the equilibrium relationship between adsorbent and adsorbate, and determine the maximum capacity of adsorption. The common used isotherm models are the Langmuir and Freundlich isotherms.

\section{1) Langmuir isotherm}

The Langmuir isotherm is the simplest theoretical model for monolayer adsorption, based on the assumption that molecules are adsorbed at a fixed adsorption site and each site can hold one adsorbate molecule. It also suggests that all sites are energetically equivalent and there is no interaction between the adsorbate molecules. The Langmuir isotherm is expressed as follows: 


$$
\frac{C_{e}}{q_{e}}=\frac{1}{b q_{m}}+\frac{C_{e}}{q_{m}}
$$

where $q_{m}$ is the maximum adsorption capacity $(\mathrm{mg} / \mathrm{g})$ and $b$ is the Langmuir constant related to the energy of adsorption (L/mg).

\section{2) Freundlich isotherm}

The Freundlich isotherm is based on the assumption that the adsorption occurs on heterogeneous surface of an adsorbent with interaction between the adsorbate molecules. The adsorption energy is non-uniform distribution over the surface. The linear form of Freundlich equation is expressed as:

$$
\log q_{e}=\log K_{F}+\frac{1}{n} \log C_{e}
$$

where $K_{F}$ and $n$ are the Freundlich constant related to adsorption capacity and adsorption intensity, respectively [9], [13].

\section{G. Thermodynamic Parameters}

The effect of temperature on the adsorption of $\mathrm{Cd}$ (II) and $\mathrm{Zn}$ (II) ions onto bottom ash was studied at four temperatures $\left(10,20,30\right.$ and $\left.40^{\circ} \mathrm{C}\right)$ in $50 \mathrm{mg} / \mathrm{L}$ metal solution. These studies were carried out at the optimum $\mathrm{pH}$ value obtained from the previous batch adsorption studies.

The thermodynamic parameters of the adsorption such as the Gibbs free energy change $\Delta G^{\circ}(\mathrm{kJ} / \mathrm{mol})$, the standard enthalpy change $\Delta \mathrm{H}^{\circ}(\mathrm{kJ} / \mathrm{mol})$ and the standard entropy change $\Delta S^{\circ}(\mathrm{J} / \mathrm{mol} . \mathrm{K})$ were calculated using the following equations:

$$
\begin{aligned}
& \Delta G^{\circ}=-R T \ln K_{e} \\
& \ln K_{e}=\frac{\Delta S^{\circ}}{R}-\frac{\Delta H^{\circ}}{R T} \\
& \Delta G^{\circ}=\Delta H^{\circ}-T \Delta S^{\circ}
\end{aligned}
$$

where $K_{e}$ is the equilibrium constant, $T$ is the absolute temperature $(\mathrm{K})$ and $\mathrm{R}$ is the universal gas constant $(8.314$ $\mathrm{J} / \mathrm{mol} . \mathrm{K})$ [13], [15].

\section{RESUlts AND DisCUSSION}

\section{A. Properties of Adsorbent}

\section{TABLE I: CHEMICAL COMPOSITIONS OF BOTTOM ASH}

\begin{tabular}{ll}
\hline \hline Chemical compositions & Weight percent (\%) \\
\hline $\mathrm{SiO}_{2}$ & 38.3 \\
$\mathrm{CaO}$ & 18.0 \\
$\mathrm{Al}_{2} \mathrm{O}_{3}$ & 17.0 \\
$\mathrm{Fe}_{2} \mathrm{O}_{3}$ & 15.8 \\
$\mathrm{SO}_{3}$ & 5.62 \\
$\mathrm{MgO}$ & 2.46 \\
$\mathrm{~K}_{2} \mathrm{O}$ & 2.15 \\
$\mathrm{TiO}_{2}$ & 0.553 \\
$\mathrm{Mn}_{2} \mathrm{O}_{3}$ & 0.117 \\
\hline \hline
\end{tabular}

Study on the physical and chemical properties of bottom ash showed that bottom ash was slightly alkaline at $\mathrm{pH}$ of 8.84. The density, particle size distribution and moisture content were $2.43 \mathrm{~g} / \mathrm{cm}^{3}, 24.553 \mu \mathrm{m}$ and $2.30 \%$, respectively. The CEC value of bottom ash was $10.56 \mathrm{cmol} / \mathrm{kg}$. The specific surface area, which measured using BET method, was $5.14 \mathrm{~m}^{2} / \mathrm{g}$. The chemical compositions of bottom ash were determined by XRF as shown in Table I. The major chemical components were $\mathrm{SiO}_{2} 38.3 \%, \mathrm{CaO} 18.0 \%, \mathrm{Al}_{2} \mathrm{O}_{3}$ $17.0 \%$ and $\mathrm{Fe}_{2} \mathrm{O}_{3} 15.8 \%$.

\section{B. Effect of $P H$}

The $\mathrm{pH}$ of solution is the most significant parameters for adsorption of metal ions. The change of $\mathrm{pH}$ affects the surface charge of the adsorbent, the degree of ionization of adsorbate and the chemical speciation of metal ions. The adsorption of $\mathrm{Cd}$ (II) and $\mathrm{Zn}$ (II) ions onto bottom ash at different values of $\mathrm{pH}(4,5$ and 6$)$ was shown in Fig. 1. The removal of $\mathrm{Cd}$ (II) and $\mathrm{Zn}$ (II) ions significantly increased when $\mathrm{pH}$ value increased from 4 to 6 .

At low $\mathrm{pH}$ values, the removal of metal ions decreased because of the fact that the surface charge is not suitable for adsorption. The increase in positively charged surface sites when $\mathrm{pH}$ decrease leads to electrostatic repulsion between the surface positive charges and the cationic metal ions. In addition, a higher concentration of $\mathrm{H}^{+}$ions in solution can compete with metal ions for the adsorption sites, resulting in the decreased adsorption of metal ions. The positive charge develops on the oxide surface of adsorbent in an acidic solution. The reaction can be represented as:

$$
-\mathrm{MO}+\mathrm{H}-\mathrm{OH} \stackrel{\mathrm{H}^{+}}{\longrightarrow} \mathrm{M}-\mathrm{OH}^{2+}+\mathrm{OH}^{-}
$$

According to the simple speciation diagrams for $\mathrm{Cd}$ (II) and $\mathrm{Zn}$ (II) ions, all the species occurring at $p H \leq 7$ contain positive charges as $\mathrm{Cd}^{2+}, \mathrm{Cd}(\mathrm{OH})^{+}, \mathrm{Zn}^{2+}$ and $\mathrm{Zn}(\mathrm{OH})^{+}$. As the $\mathrm{pH}$ increasing, the positively charged surface sites decrease and the negatively charged surface sites of adsorbent increase as shown below:

$$
\begin{aligned}
& -\mathrm{MOH}+\mathrm{OH}^{-} \rightarrow-\mathrm{MO}^{-}+\mathrm{H}_{2} \mathrm{O} \\
& -\mathrm{MO}^{-}+\mathrm{Cd} \rightarrow-\mathrm{M}-\mathrm{O}-\mathrm{Cd}
\end{aligned}
$$

The above $\mathrm{pH} 6$, the surface of the adsorbent is negative and the metal ions, $\mathrm{Cd}$ (II) and $\mathrm{Zn}$ (II) ions are still present as $\mathrm{Cd}(\mathrm{OH})^{+}$and $\mathrm{Zn}(\mathrm{OH})^{+}$ions. The adsorption of these metals under this condition is electrostatic attraction [15], [16]. Therefore, $\mathrm{pH} 6$ was chosen as the optimum $\mathrm{pH}$ for adsorption of $\mathrm{Cd}$ (II) and $\mathrm{Zn}$ (II) ions onto bottom ash.

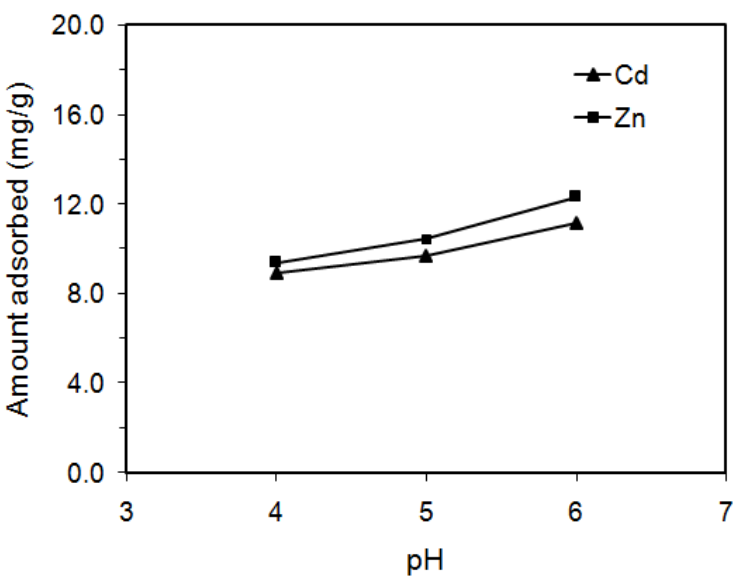

Fig. 1. Effect of $\mathrm{pH}$ on the adsorption of Cd (II) and Zn (II) ions onto bottom ash. 


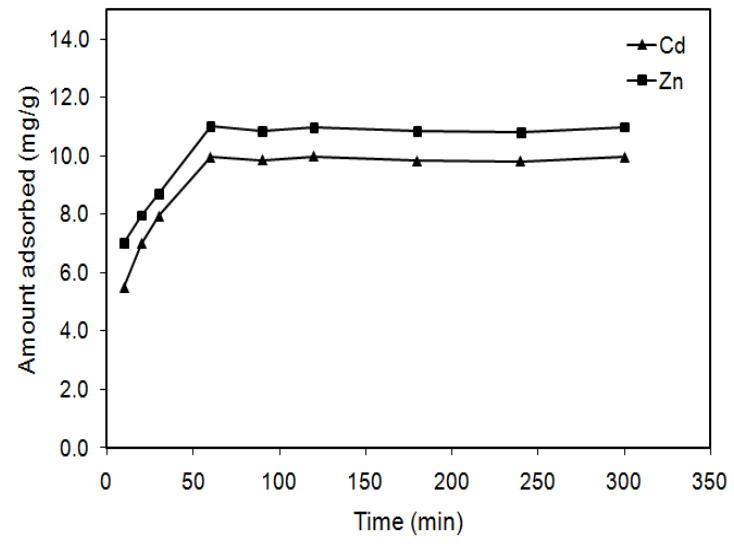

Fig. 2. Effect of contact time on the adsorption of Cd (II) and Zn (II) ions onto bottom ash.

\section{Kinetic Studies}

The effect of contact time on $\mathrm{Cd}$ (II) and $\mathrm{Zn}$ (II) ions removal by bottom ash was shown in Fig. 2. All the batch experiments indicated that the adsorption rate increased rapidly at the beginning, after that the change of rate became constant. The adsorption rate is high in the initial stages of adsorption because a large number of adsorption sites are available for the adsorption of metal ions. The adsorption of Cd (II) and Zn (II) ions increased with increasing contact time and became almost constant after $60 \mathrm{~min}$ for bottom ash. According to these results, a 60 min was used as contact time in order to ensure that equilibrium conditions were attained. To explain the adsorption kinetics, pseudo-first-order and pseudo-second-order models were tested to fit the experimental data obtained from the adsorption of $\mathrm{Cd}$ (II) and $\mathrm{Zn}$ (II) ions experiments. For pseudo-first-order model, the values of $k_{1}$ and $q_{e}$ were obtained from the slope and intercept by plotting $\log \left(q_{e}-q_{t}\right)$ versus $t$, respectively (Fig. 3). Pseudo-second-order parameters, $q_{e}, k_{2}$ and $\mathrm{h}$, were calculated from the linear plots of $t / q_{t}$ versus $t$ (Fig. 4). All the parameters of pseudo-first-order and pseudo-second-order models were determined and listed in Table II. The equilibrium amount adsorbed $\left(q_{e}\right)$ from the experiment $\left(q_{e}, \exp \right)$ and the calculation $\left(q_{e}\right.$, cal $)$ were also shown in Table II. In case of pseudo-second-order model, the calculated $q_{e}$ values agreed well with the experimental $\mathrm{q}_{\mathrm{e}}$ values. Furthermore, the correlation coefficient $\left(R^{2}\right)$ for pseudo-second-order model was much closer to 1.000 than the correlation coefficient for pseudo-first-order model. Therefore, these results confirmed that the adsorption of $\mathrm{Cd}$ (II) and Zn (II) ions onto bottom ash can be represented by pseudo-second-order kinetic model.

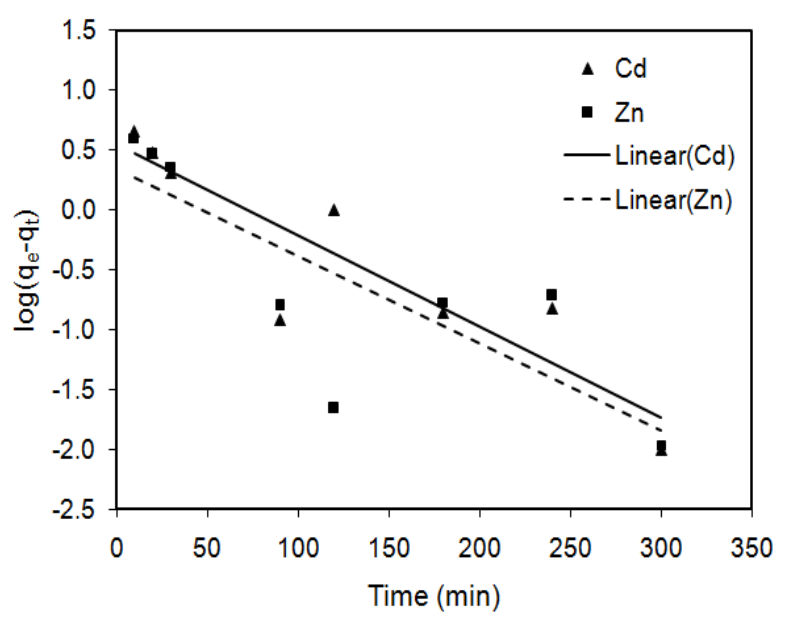

Fig. 3. Pseudo-first-order kinetic of Cd (II) and $\mathrm{Zn}$ (II) ions adsorption onto bottom ash.

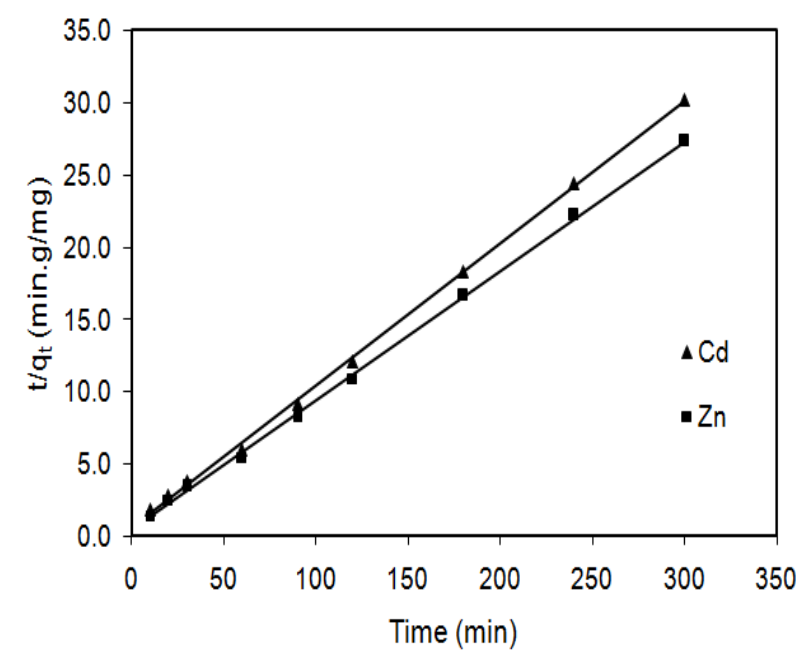

Fig. 4. Pseudo-second-order kinetic of Cd (II) and Zn (II) ions adsorption onto bottom ash.

TABLE II: ADSORPTION KINETIC PARAMETERS FOR THE ADSORPTION OF CD (II) AND ZN (II) IONS BY BOTTOM ASH.

\begin{tabular}{lll}
\hline \hline Kinetic models & Cadmium & Zinc \\
\hline$q_{\mathrm{e}}, \exp (\mathrm{mg} / \mathrm{g})$ & 9.96 & 11.00 \\
& & \\
pseudo-first-order & & \\
$q_{\mathrm{e}}, \mathrm{cal}(\mathrm{mg} / \mathrm{g})$ & 3.48 & 2.19 \\
$k_{1}\left(\mathrm{~min}^{-1}\right)$ & 0.0161 & 0.0161 \\
$R^{2}$ & 0.814 & 0.653 \\
& & \\
pseudo-second-order & & \\
$q_{\mathrm{e}}, \mathrm{cal}(\mathrm{mg} / \mathrm{g})$ & 10.20 & 11.24 \\
$k_{2}(\mathrm{~g} / \mathrm{mg} . \mathrm{min})$ & 0.0163 & 0.0170 \\
$h(\mathrm{mg} / \mathrm{g} . \mathrm{min})$ & 1.70 & 2.15 \\
$R^{2}$ & 0.999 & 0.999 \\
\hline \hline
\end{tabular}

TABLE III: LANGMUIR AND FREUNDLICH CONSTANTS FOR THE ADSORPTION OF CD (II) AND ZN (II) IONS BY BOTTOM ASH AT DIFFERENT TEMPERATURES.

\begin{tabular}{|c|c|c|c|c|c|c|}
\hline \multirow[t]{2}{*}{ Temperature $\left({ }^{\circ} \mathrm{C}\right)$} & \multicolumn{3}{|l|}{ Langmuir } & \multicolumn{3}{|l|}{ Freundlich } \\
\hline & $q_{m}(\mathrm{mg} / \mathrm{g})$ & $b(\mathrm{~L} / \mathrm{mg})$ & $R^{2}$ & $K_{F}(\mathrm{mg} / \mathrm{g})$ & $n$ & $R^{2}$ \\
\hline \multicolumn{7}{|l|}{ Cadmium } \\
\hline 10 & 11.24 & 0.0834 & 0.961 & 1.85 & 2.37 & 0.994 \\
\hline 20 & 12.05 & 0.101 & 0.979 & 2.17 & 2.39 & 0.998 \\
\hline 30 & 13.16 & 0.124 & 0.981 & 2.85 & 2.65 & 0.999 \\
\hline 40 & 13.51 & 0.164 & 0.984 & 3.64 & 3.05 & 0.996 \\
\hline \multicolumn{7}{|l|}{ Zinc } \\
\hline 10 & 12.20 & 0.0894 & 0.975 & 1.96 & 2.27 & 0.998 \\
\hline 20 & 13.16 & 0.102 & 0.982 & 2.26 & 2.30 & 0.996 \\
\hline 30 & 13.33 & 0.138 & 0.970 & 3.31 & 2.93 & 0.993 \\
\hline 40 & 14.93 & 0.172 & 0.967 & 4.41 & 3.36 & 0.990 \\
\hline
\end{tabular}




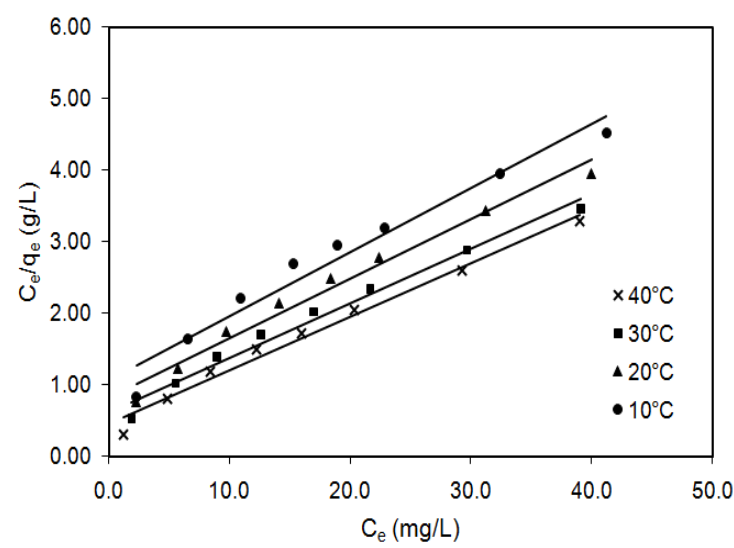

(a)

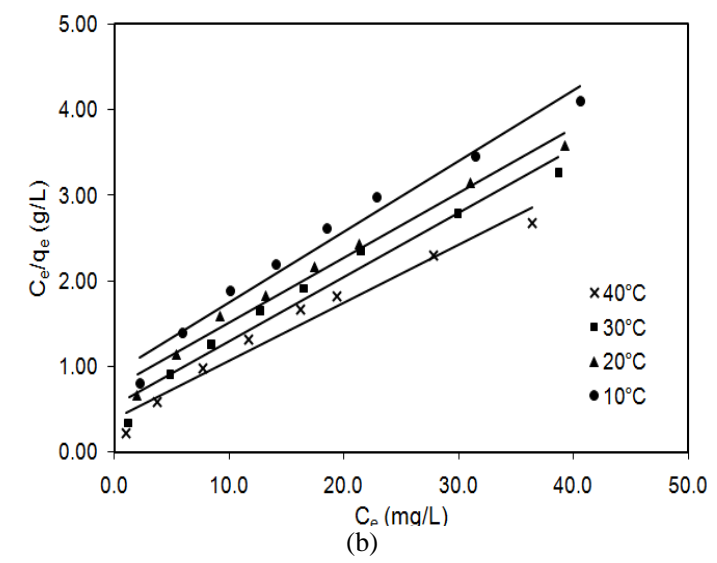

Fig. 5. Langmuir isotherms for Cd (II) (a) and Zn (II) (b) ions adsorption onto bottom ash at different temperatures.

\section{Adsorption Isotherm Studies}

The Langmuir and Freundlich isotherms were used to test the equilibrium relationship between the amount of $\mathrm{Cd}$ (II) and $\mathrm{Zn}$ (II) ions adsorbed on bottom ash, the equilibrium concentration of metal ions and the maximum adsorption capacity of bottom ash. Both isotherms, at $\mathrm{pH} 6$ and different temperatures $\left(10,20,30\right.$ and $\left.40^{\circ} \mathrm{C}\right)$, were used to determine the adsorption data at various initial concentrations of metal ions ( 5 to $50 \mathrm{mg} / \mathrm{L}$ ).

The Langmuir constants, $q_{m}$ and $b$, can be obtained from slope and intercept of the plot $C_{e} / q_{e}$ against $C_{e}$, respectively (Fig. 5). The slope and intercept of a plot of $\log \mathrm{q}_{e}$ against $\log$ $C_{e}$ were used to calculate the Freundlich constants, $n$ and $K_{F}$, respectively (Fig. 6). The Langmuir and Freundlich parameters for $\mathrm{Cd}$ (II) and $\mathrm{Zn}$ (II) ions adsorption onto bottom ash at different temperatures were given in Table III. It can be observed that the correlation coefficient $\left(R^{2}\right)$ of Freundlich isotherm was closer to unity when compared with that of Langmuir isotherm. Therefore, the Freundlich isotherm was more satisfying to fit the equilibrium adsorption data of Cd (II) and Zn (II) ions for all temperatures than the Langmuir isotherm. This can be proposed that the adsorption occurred on heterogeneous surface of bottom ash. The Freundlich parameter, n, should have values lying in the range of 1 to 10 for classification as favorable adsorption. In this study, $\mathrm{n}$ value was found to be greater than unity, so both $\mathrm{Cd}$ (II) and Zn (II) ions were favourably adsorbed by bottom ash. Moreover, the adsorption capacity $\left(K_{F}\right)$, which is the Freundlich constant, increased with an increased temperature. It indicated that the adsorption process of $\mathrm{Cd}$ (II) and $\mathrm{Zn}$ (II) ions was endothermic.

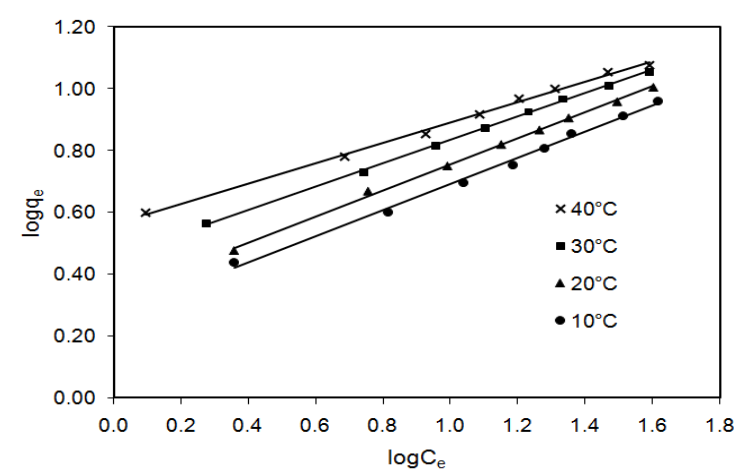

(a)

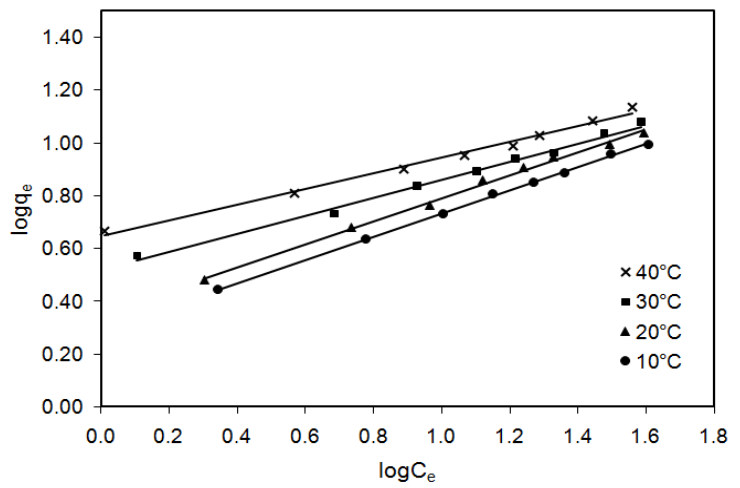

(b)

Fig. 6. Freundlich isotherms for Cd (II) (a) and Zn (II) (b) ions adsorption onto bottom ash at different temperatures.

\section{E. Thermodynamic Studies}

The plot of $\ln K_{e}$ versus $1 / T$ was used to calculate $\Delta \mathrm{H}^{\circ}$ and $\Delta \mathrm{S}^{\circ}$ from slope and intercept, respectively. The relationship between $\ln K_{e}$ and $1 / T$ was shown in Fig. 7. The thermodynamic parameters for the adsorption of $\mathrm{Cd}$ (II) and $\mathrm{Zn}$ (II) ions were indicated in Table IV.

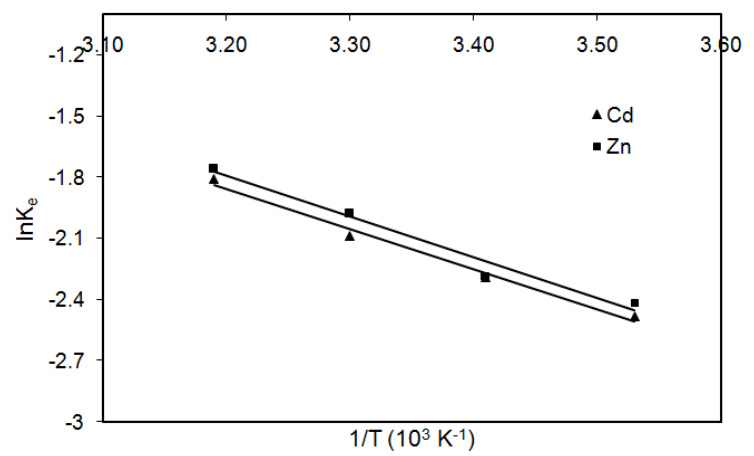

Fig. 7. Thermodynamic study for Cd (II) and $\mathrm{Zn}$ (II) ions adsorption onto bottom ash.

TABLE IV: THERMODYNAMIC PARAMETERS FOR THE ADSORPTION OF CD (II) AND ZN (II) IONS BY BOTTOM ASH.

\begin{tabular}{llll}
\hline \hline Temperature $\left({ }^{\circ} \mathrm{C}\right)$ & $\Delta \mathrm{G}^{\circ}(\mathrm{kJ} / \mathrm{mol})$ & $\Delta \mathrm{H}^{\circ}(\mathrm{kJ} / \mathrm{mol})$ & $\Delta \mathrm{S}^{\circ}(\mathrm{J} / \mathrm{mol} . \mathrm{K})$ \\
\hline Cadmium & & & \\
10 & 5.90 & & \\
20 & 5.53 & 16.41 & 37.10 \\
30 & 5.16 & & \\
40 & 4.79 & & \\
& & & \\
Zinc & & & \\
10 & 5.78 & 16.64 & \\
20 & 5.40 & & \\
30 & 5.01 & & \\
40 & 4.63 & & \\
\hline \hline
\end{tabular}


The positive value of $\Delta \mathrm{H}^{\circ}$ confirmed that the adsorption process was endothermic, which was supported by the increase of adsorption capacity when the temperature increased. The positive values of $\Delta \mathrm{S}^{\circ}$ considered the good affinity of the bottom ash towards metal ions and the increased randomness at the solid-liquid interface during the adsorption of metal ions onto bottom ash. The positive values of $\Delta \mathrm{G}^{\circ}$ resulted from the Langmuir constant (b) less than one.

\section{CONCLUSION}

Bottom ash can be used as an adsorbent for the removal of $\mathrm{Cd}$ (II) and $\mathrm{Zn}$ (II) ions from aqueous solutions. The equilibrium contact time in the removal of metal ions by bottom ash was around $60 \mathrm{~min}$. The adsorption capacity increased with increasing temperature. The adsorption equilibrium data fitted to the Freundlich isotherm model in comparison to Langmuir isotherm model at the studied temperature. The suitable kinetic model for adsorption of $\mathrm{Cd}$ (II) and $\mathrm{Zn}$ (II) ions onto bottom ash was pseudo-second-order kinetic model. The thermodynamic parameters indicated that the adsorption process of metal ions was endothermic in nature. Bottom ash is not only utilizable waste, but also low cost. Therefore, adsorbent derived from bottom ash would be useful for the economical treatment of wastewater containing metal ions.

\section{ACKNOWLEDGMENT}

This work was supported by the Higher Education Research Promotion and National Research University Project of Thailand, Office of the Higher Education Commission. The authors want to dedicate special thanks to electric power plant in Mae Moh district, Lampang Province, Thailand for bottom ash.

\section{REFERENCES}

[1] V. C. Srivastava, I. D. Mall, and I. M. Mishra, "Removal of cadmium (II) and zinc (II) metal ions from binary aqueous solution by rice husk ash," Colloids Surf. A, vol. 312, pp. 172-184, January 2008.

[2] S. Guen, B. Yao, K. Adouby, and G. Ado, "Kinetics and thermodynamics study of lead adsorption on to activated carbons from coconut and seed hull of the palm tree," Int. J. Environ. Sci. Tech., vol. 4, pp. 11-17, Winter 2007.

[3] R. A. D. Tilaki and S. Mahmood, "Study on removal of cadmium from water by adsorption on GAC, BAC and biofilter," Pak. J. Biol. Sci., vol. 7, pp. 865-869, May 2004

[4] D. Tirumalaraju and S. Mishra, "Removal of zinc from aqueous solution on $\mathrm{HCl}$ impregnated sponge iron plant waste: optimization by DOE,” Int. J. Environ. Sci. Dev., vol. 2, pp. 285-293, August 2011.

[5] C. G. Ruiz, V. Rodriguez, and B. G. Gil, "Cadmium and zinc removal from aqueous solutions by Bacillus jeotgali: $\mathrm{pH}$, salinity and temperature effects," Bioresour. Technol., vol. 99, pp. 3864-3870, June 2008.

[6] V. K. Gupta, C. K. Jain, I. Ali, M. Sharma, and V. K. Saini, "Removal of cadmium and nickel from wastewater using bagasse fly ash-a sugar industry waste," Water Res., vol. 37, pp. 4038-4044, September 2003.

[7] D. Pentari, V. Perdikatsis, D. Katsimicha, and A. Kanaki, "Sorption properties of low calorific value Greek lignites: Removal of lead, cadmium, zinc and copper ions from aqueous solutions," J. Hazard. Mater., vol. 168, pp. 1017-1021, September 2009.

[8] R. Baccar, J. Bouzid, M. Feki, and A. Montiel, "Preparation of activated carbon from Tunisian olive-waste cakes and its application for adsorption of heavy metal ions," J. Hazard. Mater., vol. 162, pp. 1522-1529, March 2009.

[9] J. X. Zhang and L. L. Ou, "Kinetic, isotherm and thermodynamic studies of the adsorption of crystal violet by activated carbon from peanut shells," Water Sci. Technol., vol. 67, pp. 737-744, February 2013.

[10] R. Kasemchaisiri and S. Tangtermsirikul, "Properties of self-compacting concrete in corporating bottom ash as a partial replacement of fine aggregate," Science Asia., vol. 34, pp. 87-95, March 2008.

[11] J. B. Gorme, M. C. Maniquiz, S. S. Kim, Y. G. Son and Y. T. Kim, "Characterization of bottom ash as an adsorbent of lead from aqueous solution,” Environ. Eng. Res., vol. 15, pp. 207-213, December 2010.

[12] A. R. Dinçer, Y. Güneş, N. Karakaya and E. Güneş, "Comparison of activated carbon and bottom ash for removal of reactive dye from aqueous solution," Bioresour. Technol., vol. 98, pp. 834-839, March 2007.

[13] H. K. Boparai, M. Joseph, and D. M. O'Carroll, "Kinetics and thermodynamics of cadmium ion removal by adsorption onto nano zerovalent iron particles," J. Hazard. Mater., vol. 186, pp. 458-465, February 2011

[14] V. C. Srivastava, I. D. Mall, and I. M. Mishra, "Characterization of mesoporous rice husk ash (RHA) and adsorption kinetics of metal ions from aqueous solution onto RHA," J. Hazard. Mater., vol. 134, pp 257-267, June 2006.

[15] T. S. Anirudhan and P. S. Suchithra, "Equilibrium, kinetic and thermodynamic modeling for the adsorption of heavy metals onto chemically modified hydrotalcite," Indian J. Chem. Technol., vol. 17 pp. 247-259, July 2010.

[16] V. C. Srivastava, I. D. Mall, and I. M. Mishra, "Equilibrium modelling of single and binary adsorption of cadmium and nickel onto bagasse fly ash," Chem. Eng. J., vol. 117, pp. 79-91, March 2006.

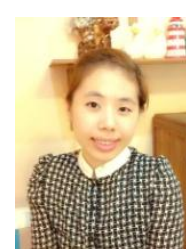

Hatairat Sukpreabprom was born in Chiang Mai, Thailand on August 27, 1984. She received the B. Sc. degree in 2006 and the M. Sc. degree in 2009 in the field of chemistry from Chiang Mai University, Chiang Mai, Thailand.

In 2006 she worked the research about production of adsorbent from bottom ash and flue gas desulfurization gypsum for adsorption of cadmium from aqueous solutions. She is now studying Ph. D. degree at Chiang Mai University, Chiang Mai, Thailand. Her research interest is the removal of heavy metal from wastewater.

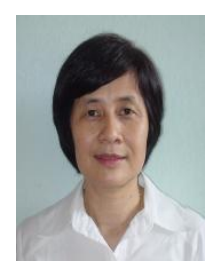

Orn-Anong Arquero was born in Chiang Mai, Thailand in 1952. She received the B. Sc. degree in chemistry from Chiang Mai University, Chiang Mai Thailand. From 1976-1980, she earned Ph.D. (Physical Chemistry) degree from Bradford University, Bradford UK

From 1985-2003, she was a postdoctoral research associate in the Karlsruhe Research Center, Karlsruhe, Germany. In 2004, she worked the research at Melbourne University, Melbourne, Australia. She had worked as lecturer in the Department of Chemistry, Chiang Mai University, Chiang Mai, Thailand until 2013.

Assist. Prof. Dr. Arquero's research interests are in adsorption study, neutron activation analysis and X-ray fluorescence and environmental study. She is an author of Surface Chemistry (published in Faculty of Science, Chiang Mai University, 1994). 